\title{
Laju Deoksigenasi Sungai Bedadung Hilir Akibat Pencemar Organik
}

\section{Deoxygenation Rate of Bedadung Downstream Due to Organic Pollutants}

\author{
AGUS DHARMAWAN, SRI WAHYUNINGSIH, ELIDA NOVITA \\ Program Studi Teknik Pertanian, Fakultas Teknologi Pertanian, Universitas Jember \\ Jalan Kalimantan No. 37 Kampus Tegalboto Jember 68121 Telp. (0331) 330244, Fax: (0331)339029 \\ Email: sriwahyuningsih.ftp@unej.ac.id
}

\begin{abstract}
Bedadung stream, located at Rambipuji, Balung, Wuluhan, and Puger, is downstream where dilution of organic wastes occurred and affects its water quality. Microorganisms decompose organic wastes and lead to depletion of dissolved oxygen in the water. The aim of this research was to analyze the deoxygenation rate of Bedadung downstream. The raw data was obtained by measuring stream flows and its water quality parameters (Temperature, $D O$ and $B O D$ ) at 5 observed stations. The laboratory analysis consisted of $B O D_{5}$ and long-term $B O D_{2,4,6,8,10}$. Increasing the value of $B O D$ for 10 days had a tendency of polynomial pattern order 3 with a coefficient of determination $R 0.8987-0.9781$. The 10 days $B O D$ reactions were used to determine deoxygenation constant $K$ (using least square method) with the result of ranged value $0.043-0.372$ /day and Ultimate BOD $1.487-8.683 \mathrm{mg} / \mathrm{L}$. The values of deoxygenation rate at 5 stations were $0.182,7.997,7.236,2.192$, and $1.083 \mathrm{mg} / \mathrm{L}$.day. The deoxygenation values were had a similar tendency with the amount of organic waste in the water column and its reduction rate due to the decomposition process.
\end{abstract}

Keywords: Bedadung, BOD, Deoxygenation Rate, DO

\begin{abstract}
ABSTRAK
Sungai Bedadung yang terletak di Kecamatan Rambipuji, Balung, Wuluhan dan Puger, merupakan sungai bagian hilir dimana zat pencemar organik bercampur, sehingga mempengaruhi kualitas perairan. Pencemar organik tersebut didekomposisi oleh mikroorganisme perairan sehingga menurunkan DO perairan. Tujuan penelitian ini adalah untuk mengkaji deoksigenasi Sungai Bedadung hilir. Data primer diperoleh dari pegukuran debit dan kualitas air (Temperatur, DO, dan BOD) di 5 (lima) titik pantau. Pengamatan $\mathrm{BOD}_{5}$ dan $\mathrm{BOD}_{2,4,6,8,10}$ dilakukan secara laboratorium. Peluruhan nilai $\mathrm{BOD}$ selama 10 hari cenderung memiliki tren polinomial dengan koefisien determinan berada pada nilai $0,8987-0,9781$. Nilai peluruhan digunakan untuk menentukan nilai $\mathrm{K}$ (menggunakan metode least square) dan BOD ultimat. Nilai K di lima titik pantau menunjukkan rentang nilai 0,043-0,372 /hari dan BOD ultimat 1,487 - 8,683 $\mathrm{mg} / \mathrm{L}$. Sedangkan laju deoksigenasi di lima titik pantau menunjukkan nilai berturut-turut 0,$182 ; 7,997$; 7,236; 2,192; dan 1,083 mg/L./hari. Besar nilai deoksigenasi sangat ditentukan oleh banyaknya kandungan pencemar organik dalam air dan kecepatan reaksinya saat proses dekomposisi.
\end{abstract}

Kata Kunci: Bedadung, BOD, Laju Deoksigenasi, DO

\section{PENDAHULUAN}

Sungai Bedadung merupakan sungai utama di DAS Bedadung yang terletak di Kabupaten Jember. DAS Bedadung berada di 16 kecamatan yaitu Panti, Sukorambi, Jelbuk, Arjasa, Patrang, Sukowono, Sumberjambe, Ledokombo, Pakusari, Sumbersari, Kalisat, Ajung, Rambipuji, Balung, Wuluhan, dan Puger, dengan total penduduk 1.378.034 jiwa pada tahun 2017(1). Sebagai sungai utama dan terbesar di Jember, Sungai Bedadung berperan dalam menunjang aktivitas penduduk. Sungai Bedadung berperan dalam menyediakan air bagi kelangsungan hidup di daerah aliran sungai, seperti untuk baku air minum, irigasi pertanian, MCK, pengendali banjir dan lain sebagainya.

Peningkatan jumlah penduduk dan perkembangan suatu kawasan di sekitar sungai mengakibatkan pola aktivitas masyarakat semakin meningkat ${ }^{(2)}$. Berbagai aktivitas manusia di sekitar sungai untuk memenuhi kebutuhan hidupnya dari kegiatan industri, domestik dan pertanian menghasilkan bahan pencemar yang dibuang ke sungai ${ }^{(3)}$.

Pencemaran air sungai akibat aktivitas penduduk dapat berupa limbah cair domestik, limbah cair industri, limbah pertanian, dan infiltrasi pembuangan air kotoran. Limbah tersebut membawa berbagai pencemar berupa 
mikroorganisme patogen, sedimen, zat hara/nutrisi, zat organik, anorganik dan lain sebagainya. Zat pencemar yang mengandung bahan organik bersifat mudah didegradasi secara biologis dengan bantuan mikroorganisme peraian. Menurut Effendi(4), bahan organik tersebut antara lain berupa lemak, protein, kanji, glukosa, aldehid, ester dan sebagainya.

Jumlah bahan organik dalam perairan dapat diketahui dari nilai BOD. BOD adalah salah satu parameter yang sering digunakan untuk mengevaluasi tingkat dan jumlah pencemar organik di perairan(5). BOD merupakan jumlah oksigen terlarut yang digunakan oleh mikroorganise dalam oksidasi biokimia bahan organik.

Oksigen yang terlarut dalam air (DO) merupakan salah satu parameter penting yang mencerminkan status kualitas air sungai(6). DO sangat vital bagi kehidupan akuatik untuk kehidupan organisme. Perubahan DO dapat digunakan untuk menggambarkan kemampuan sungai dalam membersihkan diri atau self purification $^{(7)}$ dari pencemar organik. Ketika pencemar organik masuk ke badan air, oksigen digunakan untuk mendekompoisisi bahan organik sehingga jumlah oksigen dalam air menurun $^{(8)}$. Berkurang DO air ini menunjukkan kemampuan sungai melakukan proses pembersihan diri (self purification) ${ }^{(7)}$ sehingga tercipta lingkungan yang baik untuk kehidupan mikroorganisme perairan. Akan tetapi pada kondisi alamiah, sungai juga mengalami proses reoksigenasi (penambahan DO) yang menyeimbangkan pasokan oksigen perairan karena terjadi pertukaran oksigen dari atmosfer ke badan air yang disebabkan oleh turbulensi oleh aliran sungai.
Penelitian terkait perubahan DO pernah dilakukan oleh Wahyuningsih et al. (2019)(8) pada Sungai Bedadung sebelum Bendung Bedadung (Desa Rowotamtu, Kecamatan Rambipuji) dan menunjukkan besar laju deoksigeasi 0,598 $\mathrm{mg} /$ L.hari(7). Tujuan penelitian ini adalah untuk mengkaji laju deoksigenasi Sungai Bedadung bagian hilir segmen Kecamatan Rambipuji (diawali dari setelah pengambilan irigasi Bendung Bedadung) sampai dengan Kecamatan Puger (sebelum muara) yang terjadi akibat pencemar organik dari aktivitas penduduk sekitar sungai.

\section{BAHAN DAN METODE \\ 2.1 Waktu dan Lokasi Penelitian}

Sungai Bedadung hilir yang menjadi wilayah penelitian secara administrasi berada di empat kecamatan di Kabupaten Jember, yaitu Kec. Rambipuji (setelah Bendung Bedadung, Desa Rowotamtu dan Curahmalang), Kec. Balung (Balunglor, dan Balungkulon), Kec. Wuluhan (Desa Tamansari dan Lojejer) dan Kec. Puger (Desa Wonosari). Tataguna lahan wilayah kajian adalah pemukiman penduduk, kebun dan sawah irigasi. Lokasi penelitian Sungai Bedadung hilir disajikan pada Gambar 1.

Penelitian dilakukan pada Bulan Maret sampai dengan April 2018. Data penelitian diperoleh dari pengukuran debit dan kualitas air. Pengukuran debit dan kualitas air (Temperatur dan DO) dilakukan di 5 titik pantau Sungai Bedadung hilir, sedangkan pengukuran BOD secara laboratorium dilakukan di Laboratorium Teknik Pengendalian dan Konservasi Lingkungan, Fakultas Teknologi Pertanian, Universitas Jember.

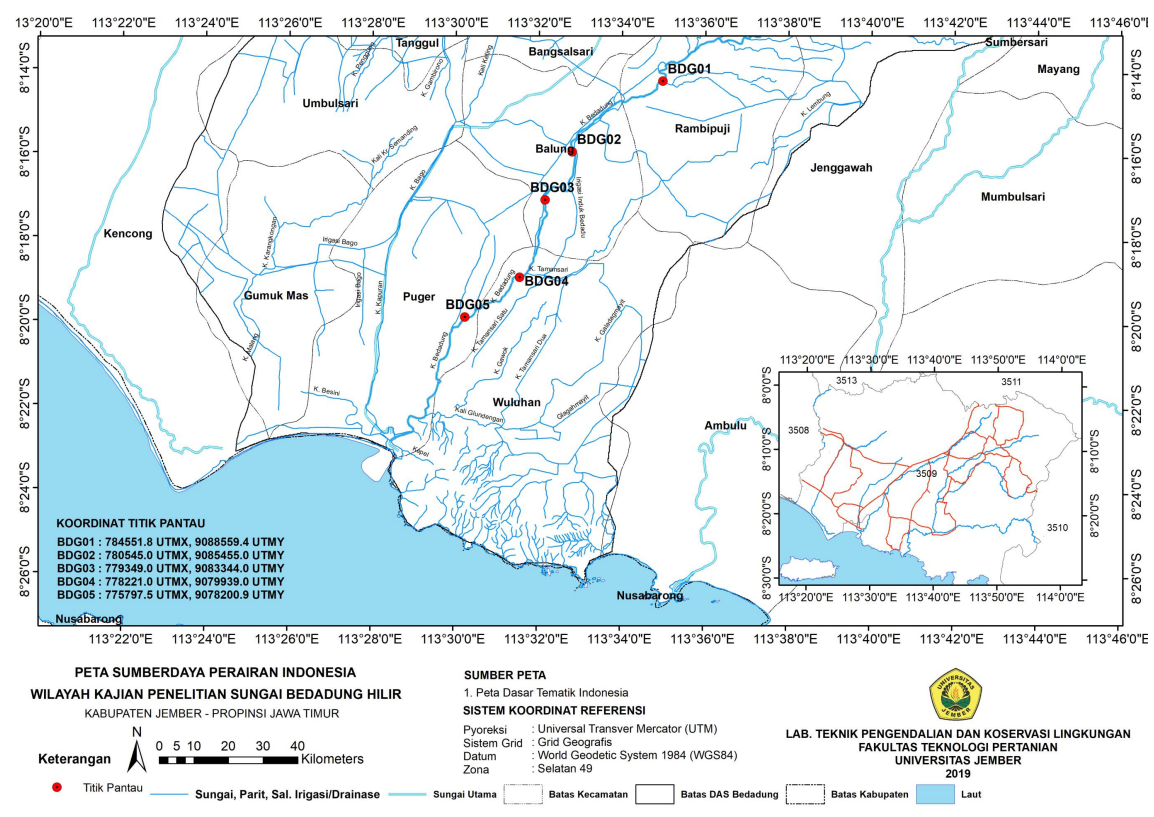

Gambar 1. Lokasi penelitian Sungai Bedadung hilir 


\subsection{Alat dan Bahan}

Peralatan penelitian terdiri atas peralatan survei dan dokumentasi (antara lain GPS dan kamera), peralatan pengukuran debit (antara lain current meter, alat ukur kedalaman, rollmeter, stopwatch, kalkulator), peralatan pengambilan contoh uji (antara lain coolbox dan botol contoh uji), peralatan analisa parameter kualitasi air (antara lain botol winkler 125 dan $250 \mathrm{~mL}$, mikroburet $2 \mathrm{~mL}$, buret $50 \mathrm{~mL}$, corong, pipet suntik $1 \mathrm{~mL}$, erlenmeyer $300 \mathrm{~mL}$ dan $2 \mathrm{~L}$, pipet volumetrik $50 \mathrm{ml}$ ). Bahan yang digunakan antara lain contoh uji air sungai, akuades, larutan $\mathrm{MnSO}_{4}$, alkali iodida azida, $\mathrm{H}_{2} \mathrm{SO}_{4}$ pekat, natrium tiosulfat, dan indikator kanji (amilum).

\subsection{Metode Penelitian}

Titik pengukuran debit ditentukan dengan mencari lokasi yang distribusi alirannya merata dan tidak ada aliran yang memutar ${ }^{(9)}$. Titik pengukuran debit yang digunakan sebagai titik pengambilan contoh uji berada pada lokasi setelah menerima zat pencemar ${ }^{(10)}$. Jarak total sungai yang dikaji adalah $15.53 \mathrm{~km}$ dengan 5 titik pantau.

Kegiatan pengukuran debit dilakukan dengan membuat profil sungai (cross section) dan mengukur kecepatan aliran. Pembuatan profil sungai dilakukan dengan mengukur lebar sungai $(L)$, membagi menjadi 10 pias dengan interval jarak yang sama, lalu mengukur kedalaman $(H)$ di setiap interval jarak sehingga memperoleh luas penampang basah $(A)$ (11). Pengukuran kecepatan aliran $(v)$ menggunakan current meter. Pengukuran $v$ dilakukan pada masing-masing pias. Debit aliran $\left(\mathrm{m}^{3} / \mathrm{s}\right)$ diperoleh dari perkalian $v(\mathrm{~m} / \mathrm{s})$ dan $A\left(\mathrm{~m}^{2}\right)$.

Pengambilan contoh uji air sungai dilakukan untuk pengukuran kualitas air dilakukan secara grab (sesaat) sehingga dapat menunjukkan karakteristik alamiah contoh uji pada saat pengambilan. Pengambilan sampel kualitas air dilakukan berdasarkan SNI 6989.57-2008 ${ }^{(10)}$. Contoh uji lalu dipreservasi pada coolbox berpendinging $\pm 4^{\circ} \mathrm{C}$. Sampel selanjutnya dibawa ke laboratorium untuk analisis parameter BOD.

Pengukuran kualitas air terdiri atas temperatur, DO dan BOD. Pengukuran temperatur dan DO di 4 titik pantau masingmasing dilakukan dengan metode termometer ${ }^{(12)}$ dan yodometri(13). Sedangkan pengukuran BOD ditetapkan berdasarkan selisih konsentrasi DO 0 hari dan konsentrasi DO 5 hari dengan menginkubasi contoh uji pada botol BOD pada temperatur $20^{\circ} \mathrm{C}^{(14)}$.

\subsection{Analisis Data}

Metode pendekatan yang digunakan dalam penelitian ini adalah menggunakan persamaan empiris untuk mengetahui besar laju deoksigenasi. Hasil pengukuran parameter lapang dan laboratorium yang diperoleh digunakan sebagai input variabel nilai. Untuk mencari besar kecepatan reduksi oksigen per hari akibat dekomposisi bahan organik yang larut dalam air, yang dinyatakan dengan laju deoksigenasi $\left(r_{D}\right)$, digunakan persamaan berikut:

$$
r_{D}=K_{D, T} \times L_{t}=K_{D} \cdot(1.047)^{T-20} \times L_{t}
$$

Menurut Haider et al., (2013) ${ }^{(6)}$, nilai $K_{D}$ diperoleh dari persamaan Hydroscience (1971) ${ }^{(6)}$

$$
K_{D}=0.3\left(\frac{H}{8}\right)^{-0.434}
$$

Nilai $L_{t}$ diperoleh dari persamaan:

$$
\begin{aligned}
& L_{t}=L_{o} \cdot e^{(-K . t)} \ldots \ldots \ldots \ldots \ldots \ldots \ldots \ldots \ldots \ldots \\
& \text { dan } L_{0} \text { didapat dari persamaan }
\end{aligned}
$$

$$
L_{0}=\frac{B O D_{5}}{\left(1-e^{-K . t}\right)}{ }^{(15)}
$$

Penentuan konstanta reaksi bahan organik $(K)$ pada botol BOD ditentukan menggunakan metode least square menggunakan pengamatan BOD selama 10 hari dengan interval waktu

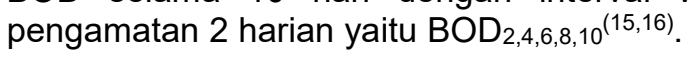

Keterangan symbol: $r_{\mathrm{D}}=$ laju deoksigenasi (mg/L.hari), $K_{\mathrm{D}}=$ konstanta deoksigenasi (/hari), $L_{\mathrm{t}}=$ bahan organik residual $(\mathrm{mg} / \mathrm{L}), \mathrm{BOD}_{5}=\mathrm{BOD}$ 5 hari $(\mathrm{mg} / \mathrm{L}), L_{0}=\mathrm{BOD}$ ultimat (total) perairan (mg/L), $\mathrm{t}=$ waktu (detik), dan $H=$ kedalaman sungai rata-rata $(\mathrm{m})$.

\section{HASIL DAN PEMBAHASAN}

\subsection{Debit dan Kualitas Air Sungai Bedadung} Hilir

Penampang Sungai Bedadung hilir di tiap titik pantau menunjukkan karateristik yang berbeda. Semakin ke hilir, sungai semakin lebar dan penampang basah semakin luas. Kedalaman Sungai Bedadung hilir cenderung juga menunjukkan perbedaan. Kecepatan aliran air Sungai Bedadung hilir pada titik pengambilan BDG02 dan BDG03 menunjukkan nilai yang tinggi karena profil sungai yang menurun. Kondisi yang penampang basah dan profil aliran air menentukan nilai debit terhitung. Kondisi Sungai Bedadung hilir di 5 titik pantau disajikan pada Gambar 2. 

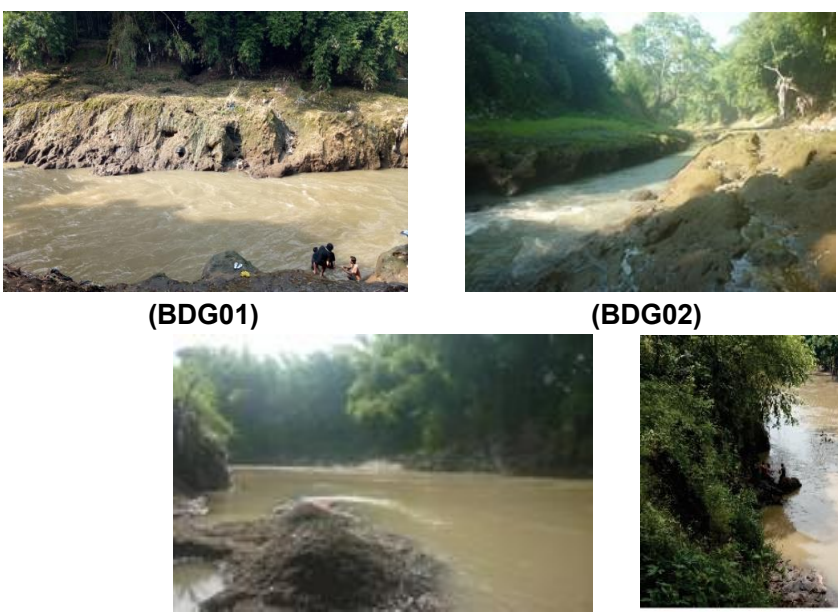

(BDG02)
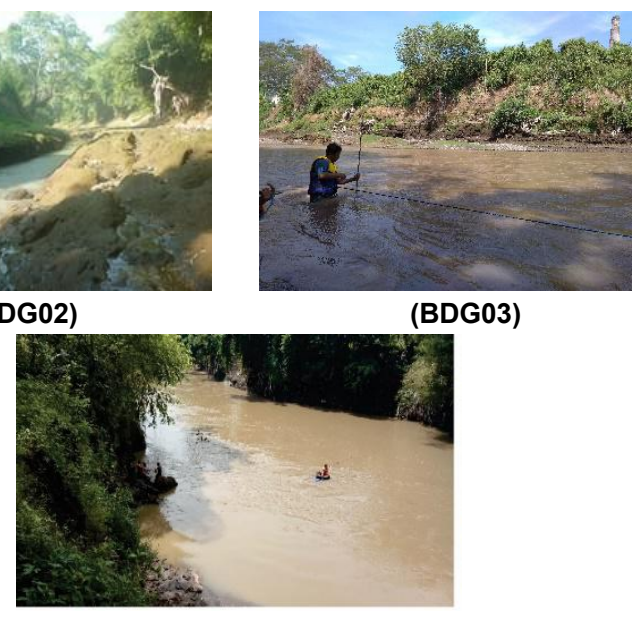

(BDG04)

(BDG05)

Gambar 2. Kondisi Sungai Bedadung hilir

Tabel 1. Profil hidraulik dan kualitas air Sungai Bedadung

\begin{tabular}{|c|c|c|c|c|c|c|c|c|c|c|c|}
\hline \multirow{3}{*}{$\begin{array}{c}\text { Titik } \\
\text { Pantau }\end{array}$} & \multicolumn{5}{|c|}{ Profil hidraulik sungai } & \multicolumn{6}{|c|}{ Kualitas air (mean/SD) } \\
\hline & \multirow{2}{*}{$\begin{array}{l}\text { Lebar } \\
(L, m)\end{array}$} & \multirow{2}{*}{$\begin{array}{c}\text { Kedalaman } \\
(h, m)\end{array}$} & \multirow{2}{*}{$\begin{array}{c}\begin{array}{c}\text { Luas } \\
\text { penampang }\end{array} \\
\left(\mathrm{A}, \mathrm{m}^{2}\right)\end{array}$} & \multirow{2}{*}{$\begin{array}{c}\begin{array}{c}\text { Kecepatan } \\
\text { aliran }\end{array} \\
(\mathbf{v}, \mathrm{m} / \mathrm{s})\end{array}$} & Debit & \multicolumn{2}{|c|}{ Temperatur } & \multicolumn{2}{|c|}{ DO } & \multicolumn{2}{|c|}{ BOD } \\
\hline & & & & & $\mathbf{Q Q}$, & \multicolumn{2}{|c|}{$\left({ }^{\circ} \mathrm{C}\right)$} & \multicolumn{2}{|c|}{ (mg/L) } & \multicolumn{2}{|c|}{ (mg/L) } \\
\hline BDG01 & 14.5 & 1.04 & 15.04 & 0.24 & 3.891 & 26.0 & 10.00 & 7.647 & 10.39 & 1.043 & 10.04 \\
\hline BDG02 & 08.0 & 0.42 & 3.36 & 0.79 & 3.038 & 28.0 & 10.00 & 6.681 & /0.17 & 1.234 & 10.37 \\
\hline BDG03 & 18.5 & 0.87 & 15.63 & 0.90 & 15.11 & 27.8 & 10.29 & 7.233 & 10.36 & 2.233 & $/ 0.19$ \\
\hline BDG04 & 30.0 & 0.76 & 22.83 & 0.20 & 4.452 & 30.0 & 10.00 & 7.096 & $/ 0.74$ & 1.403 & $/ 0.09$ \\
\hline BDG05 & 38.0 & 1.44 & 54.68 & 0.15 & 8.952 & 25.5 & 10.00 & 7.060 & $/ 0.15$ & 1.125 & 10.38 \\
\hline
\end{tabular}

Temperatur air memberi pengaruh yang signifikan terhadap proses fisika, kimia dan biologi perairan ${ }^{(17)}$. Peningkatan temperatur air menyebabkan tingginya laju metabolisme dan berbagai reaksi kimia, serta menurunkan daya larut oksigen dalam air(18). Setiap kenaikan temperatur $10^{\circ} \mathrm{C}$ akan menyebabkan terjadinya peningkatan konsumsi oksigen oleh mikroorganisme 2-3 kali lipat ${ }^{(4)}$. Kisaran temperature air optimal bagi kehidupan fitoplankton $20-30^{\circ} \mathrm{C}^{(4)}$ dan ikan $28-32{ }^{\circ} \mathrm{C}^{(18)} \mathrm{di}$ perairan tropis.

Dari penelitian yang dilakukan, temperatur air Sungai Bedadung hilir berada pada nilai antara $26^{\circ} \mathrm{C}$ dan $30^{\circ} \mathrm{C}$. Dari setiap hari pengambilan nilai temperatur air tidak mencapai batas deviasi $3^{\circ} \mathrm{C}$ dari temperatur alamiahnya, yaitu $28^{\circ} \mathrm{C}$. Air Sungai Bedadung hilir masih berada pada temperatur optimal bagi kehidupan biota perairan. Kondisi temperatur air selalu berubah setiap waktu karena faktor lingkungan.

Sebaran oksigen terlarut sangat bergantung pada temperatur air. Hal tersebut dikarenakan kelarutan gas secara langsung sebanding dengan tekanan parsial yang dipengaruhi temperatur pada kondisi seimbang ${ }^{(19)}$.
Perubahan temperatur dapat berakibat pada pengurangan oksigen ${ }^{(20)}$. Semakin tinggi temperatur suatu perairan, maka kelarutan oksigen akan semakin berkurang. Peningkatan temperatur $1^{\circ} \mathrm{C}$ akan meningkatkan konsumsi oksigen sekitar 10\% akibat penggunaan oleh mikroorganisme untuk mendekompoisi bahan organik, respirasi biota perairan, dan oksidasi bahan anorganik ${ }^{(4)}$. Temperatur juga mempengaruhi pencampuran pencemar organik. Peningkatan temperatur berarti meningkatnya laju oksidasi menurunkan kapasitas oksigen saturasi dan kecepatan difusinya, bahkan dapat menghambat pertumbuhan biota akuatik ${ }^{(20)}$.

Oksigen terlarut sangat berperan penting bagi respirasi ikan dan metabolisme mikroorganisme perairan (21). Apabila penurunan DO berada di bawah batas yang direkomendasikan untuk kehidupan biota air, maka akan sangat membahayakan ${ }^{(20)}$. Nilai oksigen terlarut air selain disebabkan oleh kelarutan oksigen akibat temperatur, juga disebabkan oleh terjadinya turbulensi akibat pergerakan air(22).

Pengukuran DO di kelima titik pantau Sungai Bedadung hilir menunjukkan nilai pada kisaran 
6,681 - 7,647 mg/L. Nilai DO memiliki nilai signifikan > $7.000 \mathrm{mg} / \mathrm{L}$ (BDG01, BDG03, BDG04, BDG05) pada akhir musim hujan dan < $7,000 \mathrm{mg} / \mathrm{L}$ (BDG02) pada awal masuk musim kemarau. Meskipun kecepatan aliran pada BDG02 tinggi, belum tentu dapat menunjukkan secara eksplisit terjadinya pertukaran oksigen dari atmosfer. Masuknya limbasan (run-offs) dan penggunaan oksigen terlarut untuk mendekomposisi bahan organik menurunkan oksigen terlarut di perairan.

Asupan oksigen perairan, berasal dari masukan aliran air dan reaerasi di dalam sungai(22). Oksigen tersebut kemudian digunakan untuk oksidasi material yang terdegradasi dari bahan organik (BOD) yang berasal dari masukan aliran air (limpasan dan anak sungai) yang mengandung zat pencemar. Konsentrasi pencemar organik tersebut akan akan menurunkan DO. Selama oksigen tersedia, proses dekomposisi bahan organik secara aerob akan terjadi hingga oksigen menipis ${ }^{(23)}$.

BOD menunjukkan jumlah oksigen yang dikonsumsi/dibutuhkan oleh bakteri untuk dekomposisi bahan organik yang terlarut dan sebagian zat-zat organik yang tersuspensi dalam air(24). BOD adalah parameter yang sering

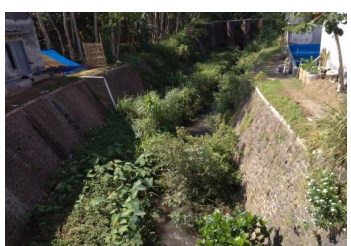

(a)

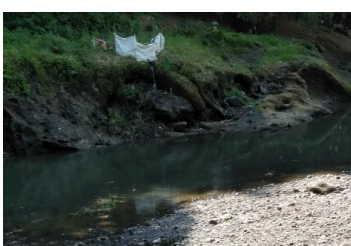

(b)

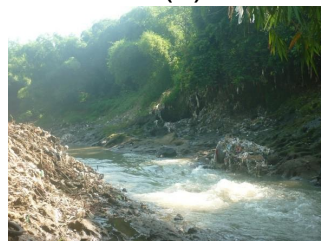

(e)

digunakan untuk mengetahui beban pencemar organik dalam air ${ }^{(17)}$. Hasil pengkuran BOD di keempat titik pantau menunjukkan nilai pada rentang 1,043 - 2,233 $\mathrm{mg} / \mathrm{L}$. Dari hasil pengukuran, BOD tertinggi berada di BDG02 sebesar 2,233 mg/L. Tingginya nilai BOD pada BDG02 karena sepanjang sungai sebelum titik pantau, zat pencemar masuk ke sungai dari pembuangan akitivitas penduduk. Pencemaran tersebut antara lain limpasan perumahan penduduk, MCK, sampah pasar, kotoran ternak, dan tumpukan sampah. Limpasan zat pencemar organik yang masuk ke Sungai Bedadung disajikan pada Gambar 3. Pencemar mengandung senyawa organik yang menjadikan BOD pada BDG02 paling tinggi. Ketika pencemar tersebut langsung dibuang ke sungai tanpa pengolahan terlebih dahulu maka akan menurunkan kualitas air sungai ${ }^{(25)}$. Tingginya nilai BOD pada titik BDG02 diiringi oleh tingginya nilai DO. Selain ditentukan oleh deoksigenasi (akibat dekomposisi bahan organik), pasokan DO pada lokasi penelitian juga ditentukan dari reaerasi yang terjadi. Kondisi sungai dengan aliran cepat menjadikan terjadinya turbulensi dan perturakan oksigen dari atmosfer ke badan air.

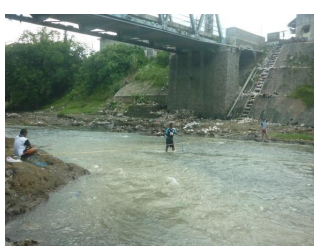

(c)

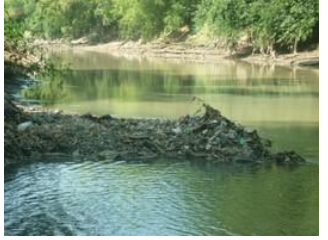

(f)

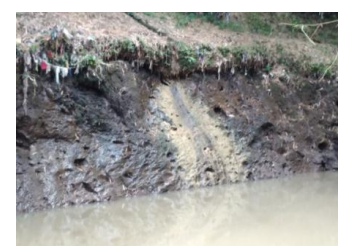

(d)

Gambar 3. Pencemaran di Sungai Bedaudung: (a) limpasan domestik, (b) buangan MCK, (c) sampah pasar, (d) kotoran ternak, dan (e) tumpukan sampah

\subsection{Laju Reaksi Bahan Organik dalam BOD}

Besar deoksigenasi bahan organik menjadi variabel penentu dalam proses kalibrasi dari simulasi DO model pada sungai(23). Dalam pemodelan kualitas air, bahan organik biodegradable diketahui menggunakan BOD, yang menunjukkan jumlah massa oksigen terlarut dalam volume tertentu yang dikonsumsi oleh mikroorganisme dalam satuan waktu(26). Selama proses tersebut, mikroorganisme menggunakan oksigen untuk mendekomposisi bahan organik dalam air. Oksidasi BOD di sungai secara alami melibatkan proses yang berbeda yang tidak terjadi dalam botol BOD, sehinga nilai laju deoksigenasi sungai $\left(\mathrm{K}_{\mathrm{D}}\right)$ berbeda dengan laju BOD dalam botol $(K)^{(6)}$. Oksidari BOD pada sungai bergantung pada kondisi lingkungan perairan. Berbeda dengan oksidasi dalam botol BOD yang terkontrol oleh faktor lingkungan luar.

Analisa BOD dalam botol dilakukan pada interval hari 2, 4, 6, 8, dan 10 . Hasil peluruhan bahan organik dalam BOD botol disajikan pada Tabel 2 dan Gambar 4. Dari Gambar 4, terlihat peningkatan nilai BOD selama 10 hari inkubasi botol. Model BOD dalam 10 hari memiliki kecenderungan tren grafik polynomial orde 3 dengan koefisien determinasi R 0,8987 - 0,9731. 
Tabel 2. Hasil analisa peluruhan BOD laboratorium

\begin{tabular}{cccccc}
\hline Hari & \multicolumn{5}{c}{ BOD $_{\mathrm{t}}(\mathrm{mg} / \mathrm{L})$} \\
\cline { 2 - 6 } ke- & BDG01 & BDG02 & BDG03 & BDG04 & BDG05 \\
\hline 0 & 0.000 & 0.000 & 0.000 & 0.000 & 0.000 \\
2 & 0.801 & 0.980 & 0.200 & 0.213 & 0.695 \\
4 & 1.087 & 1.530 & 1.130 & 1.139 & 0.818 \\
6 & 1.271 & 1.530 & 1.930 & 1.963 & 1.861 \\
8 & 1.396 & 1.780 & 2.560 & 2.395 & 1.513 \\
10 & 1.477 & 2.021 & 2.620 & 2.493 & 1.861 \\
\hline
\end{tabular}
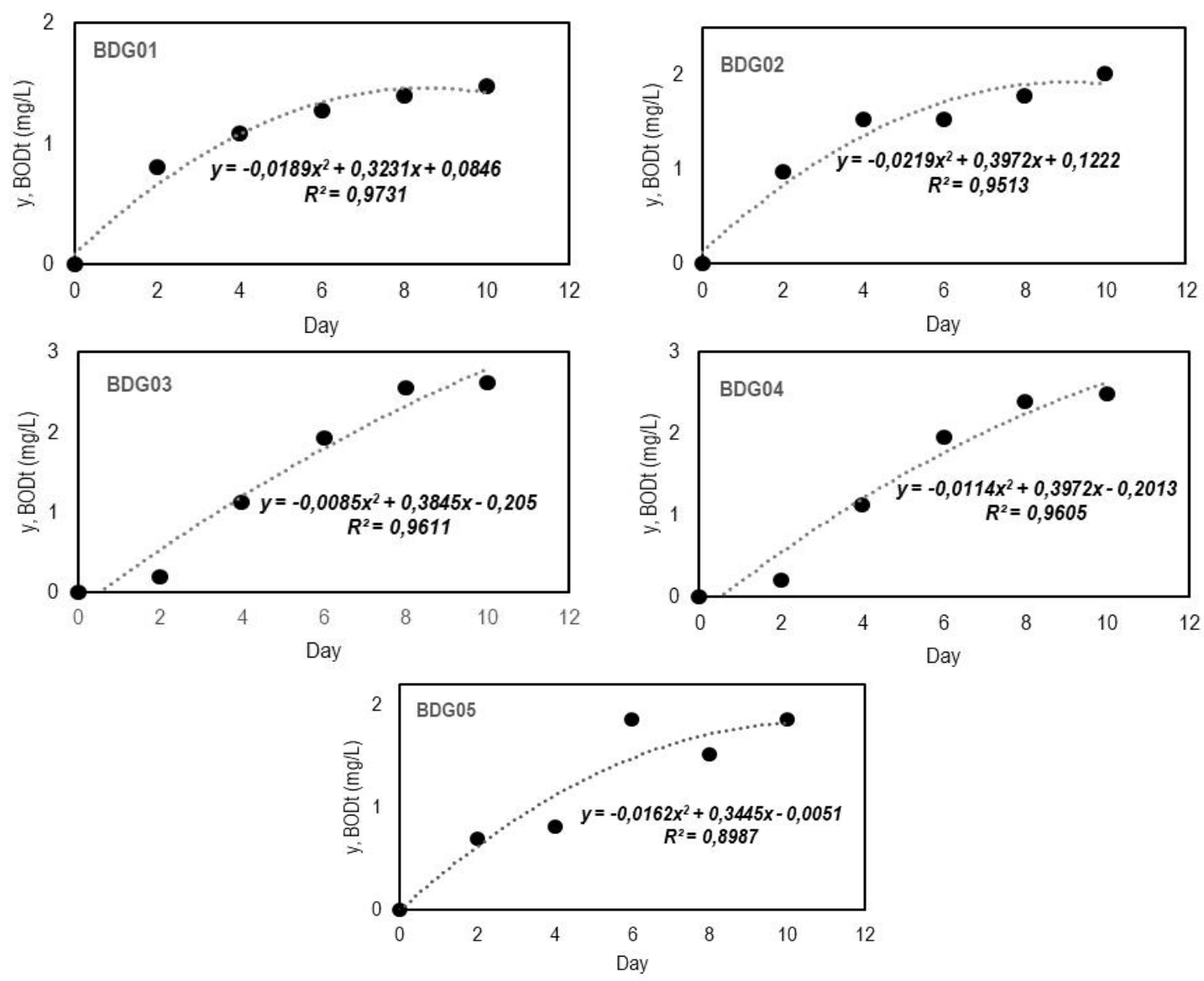

Gambar 4. Tren long-term peluruhan BOD

\subsection{Penentuan nilai K dan BOD Ultimat}

Dekomposisi bahan organik secara biologis merupakan fenomena kompleks. Hasil BOD secara laboratorium tidak semata mampu menggambarkan kondisi sungai aktual(16). Namun demikian analisa BOD umum dilakukan untuk menentukan laju reaksi BOD.

Laju BOD dalam botol dapat digunakan untuk menentukan nilai $\mathrm{K}$ dan $\mathrm{L}_{0}$ (BOD ultimat). $\mathrm{K}$ adalah laju oksidasi BOD dalam botol dan Lo adalah jumlah bahan organik biodegradable yang mampu dioksidasi dalam BOD botol(6). Penentuan nilai deoksigenasi $\mathrm{K}$ dan $\mathrm{L}_{0}$ menggunakan metode Least Square ${ }^{(15)}$. Hasil perhitungan nilai $\mathrm{K}$ dan Lo disajikan pada Tabel 4. Nilai K menunjukkan fluktuasi berada pada kisaran nilai 0,043 dan 0,372 /hari, sedangkan nilai Lo berada pada kisaran nilai 1,213 dan $8,659 \mathrm{mg} / \mathrm{L}$. Besar nilai tersebut ditentukan dari kandungan pencemar organik yang ada di perairan.

Tabel 4. Nilai K dan UBOD

\begin{tabular}{lll}
\hline Titik pantau & K (/hari) & Lo $(\mathrm{mg} / \mathrm{L})$ \\
\hline BDG01 & 0.372 & 1.580 \\
BDG02 & 0.370 & 1.213 \\
BDG03 & 0.043 & 6.372 \\
BDG04 & 0.060 & 8.659 \\
BDG05 & 0.120 & 2.457 \\
\hline
\end{tabular}




\subsection{Laju Deoksigenasi Sungai Bedadung}

Pengurangan oksigen dalam air akibat proses biokimia ditentukan dalam laju deoksigenasi $\left(\mathrm{r}_{\mathrm{D}}\right)^{(23)}$. Laju deoksigenasi mengindikasikan kecepatan reduksi oksigen per hari akibat dekomposisi bahan organik yang larut dalam air. Laju deoksigenasi dipengaruhi oleh konstanta dekomposisi $\left(\mathrm{K}_{\mathrm{D}}\right)$ dan BOD. Hasil perhiungan $\mathrm{r}_{\mathrm{D}}$, disajikan pada Gambar 5 .

Angka konstanta kecepatan dekomposisi $\left(K_{D}\right)$ menunjukkan besarnya laju penguraian bahan organik oleh mikroorganisme aerob dalam perairan ${ }^{(27)}$. Konstanta dekomposisi bahan organik pada perairan sungai berbeda dengan konstanta dokomposisi pada botol BOD karena pertimbangan faktor alamiah sungai ${ }^{(6)}$. Persamaan Hydroscience (1971) digunakan karena indikasi bahwa kedalaman $(\mathrm{H})$ sungai mempengaruhi kehidupan mikroorganisme karena semakin dalam sungai semakin rendah suplai oksigen terlarut dan sedikit mikroba yang dapat bertahan hidup pada kondisi tersebut(26). Nilai $K_{D}$ berada pada kisaran nilai 0,813 dan 1,556 /hari. Sedangkan $L_{t}$ menunjukkan besar konsentrasi oksigen terlarut yang dibutuhkan untuk mendegradasi bahan organik (biodegradable) yang ada dalam perairan secara alami. Nilai $L_{t}$ sangat bergantung pada pencemar organik yang ada pada perairan. Hasil perhitungan $L t$ berada pada nilai 0,190 - 6,426 $\mathrm{mg} / \mathrm{L}$ atau seiring dengan fluktuasi $B O D$ di kelima titik pantau.

Laju deoksigenasi Sungai Bedadung hilir berada pada rentang nilai terendah 0,182 $\mathrm{mg} / \mathrm{L}$.hari sampai tertinggi $7,992 \mathrm{mg} / \mathrm{L}$. hari. Laju deoksigenasi tertinggi berada pada BDG02 dan BDG03 berturut-turut sebesar 7,997 dan 7,236 $\mathrm{mg} / \mathrm{L}$.hari. Tingginya nilai tersebut disebabkan karena konsentrasi BOD yang berada di badan air lebih tinggi dan kecepatan dekomposisi bahan organik berlangsung sangat lambat akibat kedalaman yang mempengaruhi kehidupan mikroorganisme.

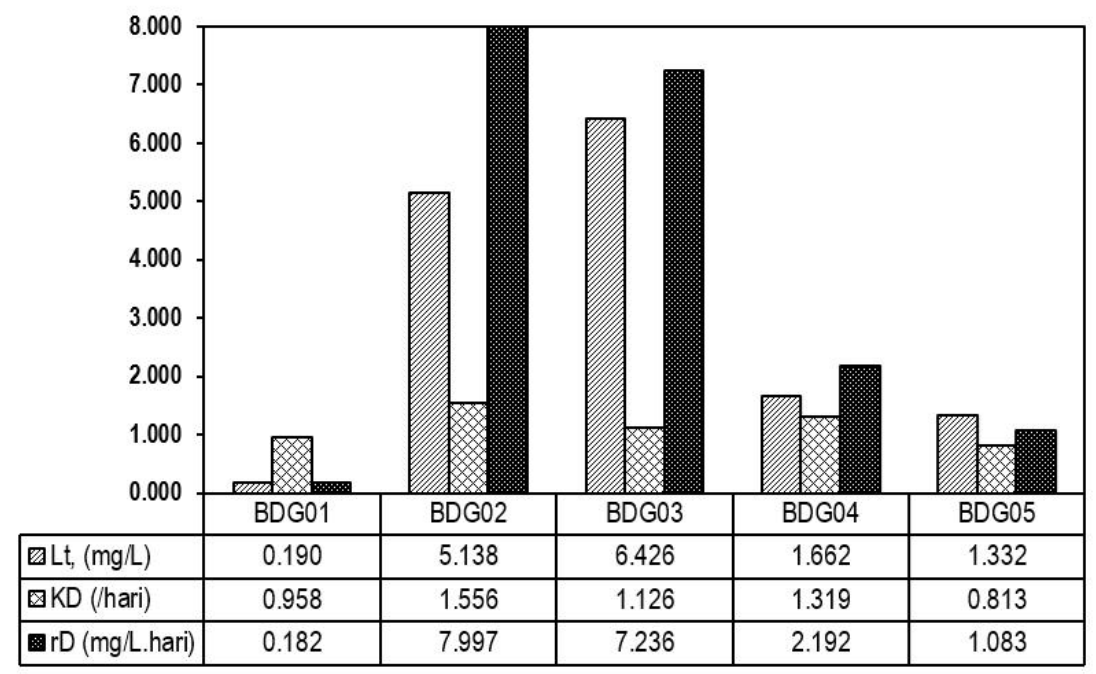

Gambar 5. Laju deoksigenasi Sungai Bedadung hilir

Pada penelitian yang dilakukan oleh Wahyuningsih et al (2019)(8) di segmen Sungai Bedadung (sebelum Bendung Bedadung, Desa Rowotamtu, Kec. Rambipuji) diperoleh besar laju deoksigenasi $0,599 \mathrm{mg} / \mathrm{L}$.hari dengan rata-rata DO $6,895 \mathrm{mg} / \mathrm{L}$ dan BOD $1,650 \mathrm{mg} / \mathrm{L}^{(7)}$. Nilai laju deoksigenasi tersebut lebih besar dari nilai BDG01 (setelah Bendung Bedadung) 0,182 $\mathrm{mg} / \mathrm{L}$.hari dengan $\mathrm{DO} 7,647 \mathrm{mg} / \mathrm{L}$ dan $\mathrm{BOD}$ $1,043 \mathrm{mg} / \mathrm{L}$. Kondisi aliran tenang yang sedikit aerasi pada segmen sebelum Bendung Bedadung menjadikan nilai DO rendah. DO tersebut selanjutnya digunakan untuk mendekomposisi bahan organik. Laju deoksigenasi akibat pencemar organik menunjukkan nilai besar akibat BOD pada lokasi tersebut tinggi. Sedangkan pada BDG01 setelah mengalami aerasi akibat air yang terjun dari mercu Bendung Bedadung dan kondisi profil sungai berbatuan menjadikan nilai DO lebih tinggi. DO tersebut lalu digunakan oleh mikroba untuk mendekomposisi bahan organik dan laju deoksigenasi lebih kecil akibat BOD pada BDG01 rendah. Fluktuasi laju deoksigenasi pada BDG02 sampai dengan BDG05 selanjutnya juga sangat ditentukan oleh kondisi sungai dan pencemar organik yang masuk ke badan air.

Dengan demikian terungkap bahwa secara umum laju deoksigenasi Sungai Bedadung sangat dipengaruhi oleh konsentrasi pencemar organik dalam perairan. Meningkatnya pencemar organik yang terkandung di badan Sungai Bedadung disebabkan oleh pertambahan penduduk dan aktivitas penggunaan lahan, sehingga daya dukung sungai terganggu dan mempengaruhi kemampuan sungai dalam memulihkan diri. Penduduk yang tinggal daerah sekitar aliran sungai sudah sepatutnya menjaga 
kelestarian sungai. Diperlukan suatu upaya pengendalian agar pencemar organik dari limbah domestik, pertanian dan industri dapat ditekan. Salah satu upaya adalah dengan membentuk dan menerapkan regulasi/kebijakan yang menjadikan masyarakat untuk ikut serta dan berperan aktif dalam mengurangi limbah yang dibuang ke sungai.

\section{KESIMPULAN}

Perhitungan laju deoksigenasi Sungai Bedadung hilir menunjukkan nilai fluktuatif. Nilai tertinggi berada pada BDG02 7.997 mg/L.hari dan BDG03 7.236 mg/L.hari. Tingginya laju deoksigenasi Sungai Bedadung bergantung pada konsentrasi pencemar organik dan kecepatan penguraian bahan organik

\section{DAFTAR PUSTAKA}

1. BPS. (2018). Kabupaten Jember dalam Angka 2018. Jember: Badan Pusat Statistik Kabupaten Jember.

2. Mahyudin, Soemarno, dan T. B. Pragyo. (2015). Analisis Kualitas Air Dan Strategi Pengendalian Pencemaran Air Sungai Metro di Kota Kepanjen Kabupaten Malang, J-PAL, 6(2), 105-114.

3. Agustiningsih, D., Sasongko, S. B., dan Sudarno. (2012). Analisis Kualitas Air dan Strategi Pengendalian Pencemaran Air Sungai Blukar Kabupaten Kendal. J. Presipitasi, 9(2), 64-71.

4. Effendi, H. (2003). Telaah Kualitas Air bagi Pengelolaan Sumber Daya dan Lingkungan Perairan. Yogyakarta: Kanisius.

5. Oke, I. A., Ismail, A., Lukman , S., Foghi, P. U., Adeosun, O.O., Amele, S. A., dan Bolorunduro A. K. (2016). An Improved Solution of First Order Kinetics for Biochemical Oxygen Demand. Ife J. Sci., 8(3), 739-752.

6. Haider, H., Ali, W., dan Haydar, S. (2013). A Review of Dissolved Oxygen and Biochemical Oxygen Demand Models for Large Rivers. Pakistan J. Eng. Appl. Sci., 12, 127-142.

7. Hee, Y. Y. dan Suratman, S. (2016). PhysicoChemical Parameters Profile During Dry and Wet Seasons in Southern South China Sea: Brunei Bay. Asian J. Chem., 28(10), 21462152.

8. Wahyuningsih, S., Novita, E., dan Ningtias, R. (2019). Laju Deoksigenasi dan Laju Reaerasi Sungai Bedadung Segmen Desa Rowotamtu Kecamatan Rambipuji Kabupaten Jember. J. IIm. Rekayasa Pertan. dan Biosist., 7(1), 1-7.
9. BSN. (2015). SNI 8066: Tata Cara Pengukuran Debit Aliran Sungai dan Saluran Terbuka Menggunakan Alat Ukur Arus dan Pelampung. Jakarta: Badan Standarisasi Nasional.

10.BSN. (2008). SNI 6989.57: Mengenai Air dan Air Limbah-Bagian 57:Metode Pengambilan Contoh Air Permukaan. Jakarta: Badan Standarisasi Nasional.

11.S. Rahayu, R. H. Widodo, M. van Noordwijk, I. Suryadi, and B. Verbist, (2009). Monitoring Air di Daerah Aliran Sungai.Online]. Available: www. worldagro forestry.esdm.go.id/library/sijh/PP801Kualitas Air.pdf. [Accessed: 15-Feb-2018].

12.BSNI. (2008). SNI 6989-23: Cara Uji Suhu dengan Termometer. Jakarta: Badan Standarisasi Nasional.

13.BSNI. (2008). SNI 6989-14: Cara Uji Oksigen Terlarut dengan Yodometri (Modifikasi Azida). Jakarta: Badan Standarisasi Nasional.

14. APHA, AWS, dan WEF. (2005). Standard Methods for The Examination of Water and Wastewater. Washington DC: American Public Health Association, American Water Works Assocation, Water Environtment Federation.

15. Metcalf dan Eddy. (2004). Wastewater Engineering: Treatment and Reuse, 4th edition. New York, US: The McGraw-Hill Companies, Inc.

16. Lee, C. C. dan Lin, S. D. (2007). Handbook of Environmental Engineering Calculations, 2nd edition. New York, US: McGraw Hill Companies, Inc..

17.Barakat, A., El-Baghdadi, M., Rais, J., Aghezzaf, B., dan Slassi, M. (2016). Assessment of Spatial and Seasonal Water Quality Variaton of Oum Er Rbia River (Morocco) using Multivariate Statistical Techniques. Int. Soil Water Conserv. Res., 4, 284-292.

18. Kordi, M. G. H., dan Tancung, A. B. (2007). Pengelolaan Kualitas Air dalam Budidaya Perairan. Jakarta: Rineka Cipta.

19. Huboyo, H. S. dan Zaman, B. (2007). Analisis Sebaran Temperatur Dan Salinitas Air Limbah Pltu-PItgu Berdasarkan Sistem Pemetaaan Spasial (Studi Kasus: Pltu-PItgu Tambak Lorok Semarang)," J. Presipitasi, 3(2), 40-45.

20. Ughbebor, J. N., Agunwamba, J. C., dan Amah, V. E. (2012). Determination of Reaeration Coefficient K2 for Polluted Stream as A Function of Depth, Hydraulic Radius, Temperatur, and Velocity. Niger. J. Hydrol., 31(2), 175-180. 
21. Suriadarma, A. (2011). Dampak Beberapa Parameter Faktor Fisik Kimia terhadap Kualitas Lingkungan Perairan Wilayah Pesisir Karawang Jawa Barat. Ris. Geol. dan Pertamb., 21(2), 21-36.

22. Harsono, E. (2010). Evaluasi Kemampuan Pulih Diri Oksigen Terlarut Air Sungai Citarum Hulu. Limnotek, 17(1), 17-36.

23. Hendriarianti, E. and Karnaningroem, N. (2015). Deoxygenation Rate of Carbon in Upstream Brantas River in the City of Malang. J. Appl. Environ. Biol. Sci., 5(12), 36-41.

24. Alaerts, G. dan Santika, S. S. (1984) Metoda Penelitian Air. Surabaya: Usaha Nasional.
25. Yogafanny, E. (2015). Pengaruh Aktivitas Warga di Sempadan Sungai terhadap Kualitas Air Sungai Winongo. J. Sains dan Lingkung., $7(1), 41-50$.

26. Yustiani, Y. M., Wahyuni, S. dan Alfian, M. R. (2018). Investigation on the deoxygenation rate of water of cimanuk river, Indramayu, Indonesia. Rasayan J. Chem., 11(2), 475-481.

27. Astono, W. (2010). Penetapan Nilai Konstanta Dekomposisi Organik (Kd) Dan Nilai Konstanta Reaerasi (Ka) pada Sungai Ciliwung Hulu-Hilir. J. EKOSAINS, 2(1), 40-45. 